\title{
RELATIONSHIP BETWEEN PROSPECTIVE TEACHERS' ATTITUDE TOWARDS INFORMATION AND COMMUNICATION TECHNOLOGY (ICT) AND ITS USE FOR EDUCATIONAL PURPOSES IN GILGIT-BALTISTAN
}

\author{
Ikhlaq Hussain \\ MPhil Graduate, Department of Educational Development, \\ Karkoram International University, Gilgit \\ ikhlaqwafa89@gmail.com \\ Dil Angaiz \\ Assistant Professor, Department of Educational Development, \\ Karkoram International University, Gilgit \\ dilangaiz@kiu.edu.pk \\ Salma Jan \\ Visiting Lecturer, Department of Educational Development, \\ Karkoram International University, Gilgit \\ salma_jan49@yahoo.com
}

\begin{abstract}
The purpose of this study was to investigate the relationship between prospective teachers' attitude towards ICT and its use for educational purposes among teacher education institutions of GilgitBaltistan. All final year prospective teachers $(n=236)$ of two teacher education colleges and a public sector university were the sample of this study. The researcher has adapted Test of e-Learning Related Attitude scale to measure attitude towards ICT. Whereas, Technology Level of Use scale was used to investigate prospective teachers' use of ICT. Findings indicated that more than 90\% prospective teachers show high positive attitude towards ICT. Findings further indicated a significant difference in prospective teachers' attitude towards ICT by institution. However, no any significant difference was found among institutions regarding use of ICT. The study found weak positive correlations between use of ICT and attitude towards ICT; and program of studies and attitude towards ICT; gender and program of studies. However, attitude towards ICT was found to have inverse correlation with gender and type of institution. Similarly, inverse correlation was observed between use of ICT and gender and use of ICT and program of studies. This study will be an addition in the available literature from the context of Gilgit-Baltistan.
\end{abstract}

Keywords: Prospective Teachers, Attitude, Information and Communication Technology (ICT), ICT integration, Teacher Education Institutions

\section{INTRODUCTION}

Information Communication Technology (ICT) defined in UNESCO training module consists of all the tools that enable students and teachers to store, produce, gather, merge, correspond, control and practice information in multimedia and a variety of digital devices which is used for different educational purposes. Ion and Andreea (2008) described that ICT consist of laptop, mobile, networks, software, computers and other data processing and transmitting devices. This technology based epoch, ICT integration in education field is very necessary to boost up the education system. According to Watson (2006), ICT is a catalyst in education field. It changes the teaching methodology, learning approaches and supports students and teachers in easy access to information and knowledge. Therefore, in the last decade, ICT has emerged in education system and become an effective tool of teaching and learning process. Since then, most of the countries have changed their policies and plans to integrate ICT in educational process (Eurydice, 2011, Fraillon, Ainley, Schulz, Friedman \& Gebhardt, 2014). Many institutions especially teacher education institutes around the world had to change and improve their infrastructures. 
In this regard, Pakistan Education Policy (2009), and National Professional Standards for Teachers (2009) both focused on ICT integration in education for lifelong learning. According to Education Policy (2009), ICT gives access to a range of learning resources, which strengthens education quality by introducing ICT in teacher training institutions. It intended to train teachers for adopting ICT in new teaching styles. Similarly, National Professional Standards for Teachers emphasis on the competence, knowledge, and confidence to use variety of educational technologies. In addition, it presumes that prospective teachers will use ICT in their education and teaching practicum throughout the whole program and teaching experience, and it is a crucial element of the Bachelor of Education (B.Ed.) program. Moreover, the Vision-2025 attaches lots of significance on transformational education, practical education, innovation and creativity. Ministry of Education Pakistan and Higher Education Commission (HEC) Pakistan both focuses on use of ICT in education field for lifelong learning especially in teacher education institutions. In this regard new programs, [associate degree in education (ADE) and B.Ed (Hons)] is launched for teachers to fulfill the requirements. These programs are especially arranged to meet the objectives of National education policy 2009 and National professional standards for teachers. Consequently, majority of teacher education institutions are upgraded and provided with computer, internet, multimedia, Email, digital libraries. Moreover, Pakistan Telecommunication Authority (PTA) has introduced 3G/4G/LTE in telecom sector to make possible to progress with the world of technology.

\section{Problem Statement}

ICT has a strong positive influence on educational organizations in terms of changing believes and attitudes, innovations in educational processes, and skills. Literature suggests many factors that assist teachers in integrating ICT in meaningful learning. Research studies related to the relationships between teachers' attitude towards ICT generally suggests that teachers who hold positive attitude towards ICT seem to take more interest in involving their students in use of computers. For instance, Khine (2001) and Yuen (2001) in their studies found a significant relationship between attitude towards ICT and its use in teacher education institution. However, in the context of Pakistan, integration of ICT in many schools, students' interaction with ICT is unknown (Jan, 2018). There are many barriers which hampered the implementation of ICT in educational process. These include lack of motivation and poor attitude towards ICT. Successful ICT integration in teaching and learning process needs positive attitude of teachers towards ICT, because teachers are key roles to adopt and implement new teaching styles (Kumar, Lo, \& Chen, 2008). Hardman (2008) stated that the use of ICT and its integration in education in most of the teacher education institutions is still very minimal and inappropriate. Regardless of having number of research studies on acceptance of ICT in education many researchers (Harindranath, Dyerson, \& Barnes, 2008; Jan, 2018; Ongori \& Migiro, 2010) recommends to do further research on the key reasons or causes that hampers successful ICT integration in diverse situations in the world.

Nevertheless, numerous studies (Ahmed \& Kazimi, 2020; Jan, 2018; Khokhar \& Javaid, 2016; \& Rana, 2016) are conducted in Pakistan on attitude towards ICT and its use for educational purposes. However, it seems that no research study is conducted on prospective teachers' attitude towards ICT and its use for educational purposes in teacher education institution in Gilgit-Baltistan. Therefore, this study aims at exploring the relationship between prospective teachers' attitude towards ICT and its use for educational purposes in teacher education institutions in Gilgit.

\section{Significance of the Study}

The concept of ICT as a pedagogical tool is new and modern technique to majority of prospective teachers in Gilgit. This study will be significant in the field of teacher education and technology in the following ways:

1. The findings and recommendations of this study will be significant for prospective teachers, in term of understanding role of positive attitude in using ICT as pedagogical tool in teacher education institutions.

2. This study will provide insights to policy makers to modify and amend their policies regarding ICT integration in educational institutions based on existing situations and problems. Moreover, this study will help in determining the programs and strategies for ICT development.

3. This study will be an addition to existing literature in terms of exploring and understanding attitudes and perspectives of usage of ICT by teacher education institutions in Gilgit-Baltistan. 
4. This study will potentially benefit individuals and groups, who will read it, in understanding and exploring relationships and reasons behind issues and challenges pertaining to ICT in context of Gilgit.

\section{Research Questions}

1. What are the prospective teachers' attitudes towards ICT across teacher education institutions in Gilgit?

2. How do attitude towards ICT and use of ICT for educational purposes varied among prospective teachers enrolled in different teacher education institutions?

3. What relationship exists between prospective teachers' attitudes towards ICT and their use of ICT for educational purposes?

\section{Research Purpose and Objectives}

The purpose of this study was to look into the relationship between prospective teachers' attitude towards ICT and its use for educational purposes in teacher education institutions in Gilgit. The specific objectives for this research study were:

1. To find out prospective teachers' attitude towards ICT across the teacher education institutions in Gilgit.

2. To explore prospective teachers' use of ICT among different teacher education institutions in Gilgit.

3. To analyze the relationship between prospective teachers' attitude towards ICT and its use for educational purposes in teacher education institutions in Gilgit.

\section{Limitations of the Study}

Following are some of the limitations of this study:

1. The study is limited by the small number of prospective teacher institutions in the context of Gilgit

2. Because this study was conducted within one district, the results may not be applicable or generalized to other districts.

4. The cultural and ethnic diversity were limited due to the area in which the study took place.

5. Honesty in responses of participants as responses were self-reported. responses.

\section{REVIEW OF LITERATURE}

\section{Teachers, Teaching, and ICT}

Teachers are at the core of shaping the future of their students. They not only help students in acquiring knowledge and skills but they also inspire students to go beyond the stipulated curriculum. Teachers prepare students to challenge themselves and to push boundaries.

Due to invention of modern technological tools almost every angle of life became related to science and technology. Modern technological tools have exceptionally affected peoples' lives, their thinking, behaving and interacting with the world (Friedman, 2005). Nonetheless, these new technologies have been affecting teaching and learning process. According to Friedman (2005), this technological revolution has entered a variety of fields, including education. Undoubtedly, the technology would inspire endless learning opportunities to both students and teachers in number of ways. UNESCO World Education report (1998) insists on ICT integration in order to help students achieve academic standard.

Yekini (2014) defines Information and Communication Technology as "the convergence of audio- visual, telephone and computer networks through a link system. It is a combination of all these elements, capped by a vision on how technology can help an organization to reach its goals" (p.3). According to Hafifa (2019), ICT has become one of the basic ability that teachers must have in the in modern era. Use of different ICTs has become unavoidable for both teachers and students in the process of learning. Jan (2018) is of the view that, "ICT presents students with a new teaching and learning environment that is more collaborative and engaging" (p.26). ICT has changed the teaching methodology, learning approaches and supports students and teachers in easy access to information and knowledge (Watson, 2005). For instance, by using modern information and communication technologies, teachers and students can share, discuss and acquire required information in limited period of time. Nevertheless, "the use of digital technologies for learning has created challenges for 
schools and policy makers to incorporate new skills that become necessary in today's knowledge society" (Jan, 2018, p.26).

\section{Use of ICT in Education}

ICT is considered as an instrument through which educational institutions can enhance effectiveness of their teaching learning processes. According to Bhoomireddy and Bhatia (2004), it is very important to use ICT as tool in teaching and learning process to make it effective, innovative and transformative. Integration of ICT involves all aspects of education system such as teaching and learning, curriculum, staff development and student teaching (Ahmed \& Kazimi, 2020). Consequently, it is necessary to have skillful staff and staff ready to accept modern technology in order to enhance and boost up teaching and learning (Mostert \& Quinn, 2009). According to white paper on E-education (2004), ICT is an important factor in the educational setting in order to paradigm shift from traditional to transformational teaching and learning. Furthermore, Oliver (2000) described that in modern era ICT has a great impact on educational practices and it will continue to grow and become a strong cause for change in educational practices.

In addition, use of ICT in education process has changed the roles of teachers; now teachers have to work as facilitators and guiders (Morris, Xu, \& Finnegan, 2005), and shifts the traditional role into more active and participatory roles. Rana (2016) found several reasons in preparing prospective teachers to integrate ICT in teaching and learning processes in meaningful ways. Lack of resources and attitude towards ICT are major factors on the way of infusing ICT.

\section{Teachers Attitude towards ICT}

It is essential for prospective teachers to have positive attitude towards ICT and basic knowledge regarding ICT to integrate ICT meaningfully in education process (Koehler, Mishra, Kereluik, Shin, \& Graham, 2014). Ajzen and Fishbein (2005) states that attitude is a concept that shows ones' agreement or disagreement towards a particular object. It affects persons' beliefs and thoughts, opinion and decision regarding adoption or rejection of any object (Imtiaz \& Maarop, 2014; Straub, 2009; Teo \& Schaik, 2012). Attitude is a fundamental factor and plays a vital role in everyday life situations and in classroom settings (Ahmed \& Kazmi, 2020). Smith, Caputi and Rawstorne (2000) define computer attitude as one's general beliefs or feeling in favor or dislike toward ICT and specific computer related activities. Attitude towards ICT means individuals' beliefs, perceptions, and judgments about modern technology and it plays a vital role in framing behavior towards ICT and in implementing ICT tools in educational settings. The attitude has been found as a vital component to judge or determine prospective teachers' use of ICT (Teo, Luan, \& Sing, 2008). Al Shboul (2011) argues that there are various factors which make technology efficient in education. One of those factors is teachers' attitude towards ICT. Furthermore, he stated that ICT by itself cannot be effective. To get educational objectives, make ensure teachers and learners' participation and involvement in using technology in education process.

\section{Relationship between ICT use and Teachers' Attitude}

Number of research studies showed significant relationship between attitude towards ICT and its use. For instance, Khine (2001) stated that there is a strong relationship between attitude towards ICT and its use in teacher education organizations. Yuen (2001) described that to integrate ICT in education; there should be positive attitudes, effective usefulness, and behavioral control. Gulbahar (2008) stated that prospective teachers attitude towards ICT influence their use of ICT in teacher education institutions. Wong (2005) conducted a study in Malaysia and confirmed that teachers must have positive attitude towards ICT which enable them to use technology in effective way. Many other studies (Garland \& Noyes, 2004; Roussos, 2007; Torkzadeh, Chang, \& Demirhan, 2006) found a great significant correlation between attitude towards ICT and confidence in using ICT for educational purposes. Moreover, they suggested that positive practices with ICT plays significant role in framing positive attitude towards ICT which leads to appropriate usage of ICTs. According to Zaidiyeen, Mei, and Fong (2010), those teachers who possess positive attitudes reflects more likely to contribute and integrate ICT for educational purposes.

Nonetheless, Hafifah (2020) identified teacher's poor attitude as one of the main reasons for teacher's reluctancy towards changing traditional methods of teaching and poor integration of ICT of teaching. Similarly, Qudais, Adhaileh, and Omari (2010) identified that poor attitude towards ICT, opposition to change and anxiety of technology are main hindrances to use modern technology in educational institutions. Ihmeideh (2009) indicated that among other barriers, use ICT in education 


\section{Relationship between Prospective Teachers' Attitude Towards Information and Communication Technology}

process is poor attitude and disbelief in the role of technology to enhance education process. Successful integration of ICT needs trainings, engagement and attitude towards the use of ICT (Kalyanpur \& Kirmani, 2005; Tezci, 2011).

\section{RESEARCH METHODS}

This research study was conducted using quantitative approach to collect wide range of responses from prospective teachers on the basis of some empirical data (Creswell, 2004). Within quantitative approach, researchers used descriptive survey with the purpose to examine teachers' attitude towards ICT and its use. Census survey design was used to collect the quantitative data for this study. The reasons behind selection of census survey method were:

1. to describe trends among a group of individuals

2. to collect information from a large sample

3 . to collect data from a predetermined population.

4. to generalize the results to the entire population. Fraenkel (2002), states that census survey method helps the researcher to generalize the result to whole population.

\section{Sample and Sampling Procedure}

This study was conducted utilizing three teacher education institutions that implement new curriculum and use ICT in education. Participants were selected on volunteer basis. The population includes all the final year prospective teachers [B.Ed (Hons) \& ADE] enrolled in teacher education institutions of Gilgit. In this connection, all three teacher education institutions of Gilgit; An Elementary College of Education, A College of Education and a Local Public University were surveyed. The entire population $(\mathrm{N}=236)$ comprised of prospective teachers from the above three teacher education institutions of Gilgit participated in this survey. Out of 236 participants, female participants were $(\mathrm{F}=197)$ and male participants were $(\mathrm{M}=39)$.

\section{Establishing Reliability and Validity}

In order to find out construct validity of the tool, the tool was given to 3 experts for review. The reviewers were requested to give detailed feedback on each sections of the tool. One of the reviewers suggested dividing the tool in to Part A, B and C because each serves different purposes. Another suggested removing unnecessary questions from demographic sections and to improve the format of the questionnaire.

The reliability of research tool was examined by calculating Cronbach's alpha coefficient. The overall reliability of part B was 0.75 and part $\mathrm{C}$ was 0.65 . Both parts possessed good level of reliability.

\section{Data Collection Tools}

To achieve prime objectives of this study, a survey tool was employed. First part asks participants to provide demographics details (gender, type of institution, and program of study). Second part was meant to investigate the prospective teachers' attitude towards ICT. In this regard, "Test of e-learning Related Attitude (TeLRA) Scale was used to investigate the prospective teachers' attitude towards ICT. This questionnaire was developed by Kisanga and Ireson (2016). It consists of 26-items. TeLRA scales measure attitude towards ICT using a five-point scale of $1=$ Strongly Disagree, $2=$ Disagree, $3=$ Neutral, 4= Agree, 5= Strongly Agree. Third part investigated level of ICT use for educational purposes. Technology Level of Use for Instructional Purposes (TLUIP) scale was used to investigate level of ICT use for educational purposes. (TLUIP) scale was developed by Isleem in (2003) to investigate current level of ICT use in education. It consists of 17 items.

\section{Data Collection Procedures}

Population of this study was all final year prospective teachers enrolled in teacher education institutions in Gilgit. Initially, consents were taken from all participants via their institution heads. Informed consent letters along with detailed description of research topic with necessary introduction of the researcher was provided to the heads of departments and participants to seek permission to conduct research from institutions and participants.

After getting consents, the data from the participants were collected through survey tool onsite. The survey was conducted during the last twenty minutes of their regularly scheduled classes. Before providing research instrument, participants were advised to fill out each section in the presence of researcher and submit the filled questionnaires to researcher. Moreover, participants were instructed to write codes instead of writing their names to maintain confidentiality. Afterwards, 
research instruments were provided to all prospective teachers which measured attitude towards ICT and its use among prospective teachers. Almost all participants completely filled the given questionnaire in given time and submitted to researcher.

\section{Data Analysis}

After getting the filled questionnaire from participants, the researcher started formal data analysis using Statistical Package for the Social Sciences (SPSS). A template was developed on SPSS and data were entered using codes such as 1 for male participants and 2 for female participants. Likert scale items were coded as 1, 2, 3, 4 and 5 for strongly disagree, disagree, neutral, agree and strongly agree respectively.

Descriptive statistics were made against each question, to find mean scores and frequency distributions. Descriptive statistics help in understanding characteristics of the data. Descriptive statistics and frequencies were used to determine how prospective teachers describe their attitude towards ICT and how often a particular response was given to specific statement. For example, frequencies were used to find out how many prospective teachers actually have positive attitude towards ICT.

Consequently, T-test and ANOVA were applied to compare attitudes and use of ICT of two groups and to compare attitudes among more than two groups. In addition, Pearson product moment correlation test was used to find out the existing relationship among prospective teachers' attitude towards ICT and use of ICT by gender, by program of studies and by institutions.

\section{Demographic Analysis}

First part of the survey asked participants to provide demographic data. The demographics questions were related to gender, program of studies and type of institution. Table 1 presents details about demographic frequency distributions.

Table No. 1: Frequency distribution of variables

\begin{tabular}{|c|c|c|}
\hline Variable & Frequency & Percent \\
\hline \multicolumn{3}{|l|}{ Gender } \\
\hline Male & 39 & $17 \%$ \\
\hline Female & 197 & $83 \%$ \\
\hline \multicolumn{3}{|l|}{ Types of Institution } \\
\hline $\mathrm{ECoE}$ & 139 & $59 \%$ \\
\hline $\mathrm{CoE}$ & 41 & $17 \%$ \\
\hline Local University & 56 & $24 \%$ \\
\hline \multicolumn{3}{|l|}{ Programme of Studies } \\
\hline ADE & 159 & $67 \%$ \\
\hline B.Ed (Hons) & 77 & $33 \%$ \\
\hline
\end{tabular}

Out of 236 sample $(n=39)$ participants were male which were $17 \%$ of total population and $(n=197)$ were female which contributes $83 \%$ of total population which was the highest number of participants. Data showed variation in terms of participation from institutions. The highest number of participation was from Elementary College of Education $(n=139,59 \%)$ followed by the Local University $(n=56,24 \%)$. There was less number of participation from College of education $(n=41,17$ $\%$ ) as compare to other two institutions. In terms of Program of studies, majority of participants were ADE prospective teachers $(n=159,67 \%)$ of the population whereas participants belong to B.Ed (Hons) program were $(n=77,33 \%)$ of total population.

\section{RESULTS}

\section{Research Question One}

What are the prospective teachers' attitudes towards ICT across teacher education institutions in Gilgit?

Research question one was analyzed to find mean and standard deviation. Table 2 shows the mean and standard deviation of the items related to prospective teachers' attitude towards ICT. 
Table No. 2 Distribution of Mean Scores on the attitude scale

\begin{tabular}{llll}
\hline S.\# & Statements & Mean & SD \\
\hline 1 & ICT is less expensive for educational institutions to use. & 3.19 & 1.21 \\
2 & I believe using ICT will improve the quality of my work. & 4.44 & 0.591 \\
3 & ICT makes my work more interesting. & 4.45 & 0.722 \\
4 & I prefer reading articles in personal computer & 3.77 & 0.95 \\
5 & Learning through ICT is very easy. & 3.84 & 1.08 \\
6 & I prefer using ICT to prepare my lessons. & 3.85 & 0.88 \\
7 & I feel comfortable reading a text book on a laptop than a physical text book. & 3.04 & 1.18 \\
8 & I enjoy delivering my presentation in Multimedia. & 4.44 & 0.79 \\
9 & ICT based learning is better than face-to-face method. & 3.49 & 1.14 \\
10 & I believe using ICT technologies will improve my academic performance. & 4.08 & 0.99 \\
11 & I prefer to communicate with teachers through electronic mails/Gmail. & 3.38 & 1.15 \\
12 & I like reading magazines on new ICT technology. & 3.66 & 1.12 \\
13 & It is easier to revise electronic educational materials than printed material & 3.36 & 1.22 \\
14 & ICT technologies are easy to use. & 3.78 & 1.01 \\
15 & Discussions on ICT technologies are interesting. & 3.97 & 0.93 \\
16 & My institution has enough teaching-learning resources to use ICT. & 3.86 & 1.06 \\
17 & ICT will increase prospective teachers' efficiency. & 4.08 & 0.75 \\
18 & Working with ICT is exciting. & 3.96 & 0.74 \\
19 & ICT infrastructure is less expensive for the government to afford. & 3.63 & 1.12 \\
20 & It will be easy for me to become skilful in the use of ICT tools. & 3.94 & 0.97 \\
21 & ICT helps me improve my work better. & 4.36 & 0.62 \\
22 & ICT make it possible to work more productively. & 4.22 & 0.74 \\
23 & I enjoy computer games very much. & 4.28 & 0.82 \\
24 & ICT will provide me with better learning opportunities than traditional way of & 4.25 & 0.73 \\
25 & learning. & 3.94 & 0.87 \\
26 & I find computer online interaction exciting & 4.00 & 1.07 \\
\hline & Communicating through electronic mails is enjoyable & &
\end{tabular}

Item wise analysis presented in Table 2 indicates that majority of items scored higher than $(\mathrm{M}=3.0)$ which shows students positive attitude towards ICT. Further analysis revealed that participants have highest level of attitude towards ICT $(\mathrm{M}=4.45$; $\mathrm{SD}=0.72)$ on item 3 i.e, ICT makes my work more interesting' and item $8(\mathrm{M}=4.44 ; \mathrm{SD}=0.79)$ i,e. 'I enjoy delivering my presentation in Multimedia'. Similarly, on item 2 i.e., 'I believe using ICT improve quality of my work' respondents showed high level of attitude $(\mathrm{M}=4.44 ; \mathrm{SD}=0.59)$. It endorses that students believe in ICT as it makes their work interesting and enjoyable. Moreover, ICT is believed to improve their work and makes their learning enjoyable and interesting. Analysis further indicates that the respondent on average are 'undecided' about mentioned statements in item $1(\mathrm{M}=3.19 ; \mathrm{SD}=1.21)$, Item $7(\mathrm{M}=3.04 ; \mathrm{SD}=1.18)$, item $9(\mathrm{M}=3.49 ; \mathrm{SD}=1.14)$, item $11(\mathrm{M}=3.38 ; \mathrm{SD}=1.15)$, and item 13 $(\mathrm{M}=3.36 ; \mathrm{SD}=1.22)$. It means students were not able to decide on electronic method of teaching and learning and face to face interactions. In addition, respondents were not clear about means of communicating electronically with their teachers.

On the contrary, mean responses value for prospective teachers' attitude towards ICT also revealed that prospective teachers show low attitude towards ICT on item 7, I feel comfortable reading a text book on a laptop than a written textbook $(\mathrm{M}=3.04$; $\mathrm{SD}=1.18)$ and item 1 'ICT is less expensive for educational institutions to use' $(\mathrm{M}=3.19 ; \mathrm{SD}=1.21)$. However, on all other remaining items, mean values show that respondents possess almost same level of positive attitudes towards ICT. It means prospective teachers consider ICT useful for their teaching and learning processes. They enjoy computer games and ICT makes it possible to work more productively. They further believe that ICT enhances their efficiency and provides them better learning opportunities.

When prospective teachers' attitude towards ICT was seen in terms of percentages, the frequency distribution shows that more than $90 \%$ participants show high attitude towards ICT. For instance, 95\% participants accept that ICT makes their work more interesting and it improves their work. $92 \%$ prospective teachers enjoy multimedia presentations and $90 \%$ enjoy computer games. 
Frequency table further revealed that the highest percent of respondent $42 \%$ disagree and they do not believe that, ICT is less expensive for educational purposes. Moreover, $31 \%$ prospective teachers do not agree with the statement that it is easier to revise electronic materials than printed one. Moreover, $60 \%$ participants show undecided attitude towards ICT believing that, ICT infrastructure is less expensive for the government to afford; similarly 50.4\% prospective teachers were undecided to believe that using ICT will raise the quality of their work.

In order to find differences within the groups, multiple comparisons were employed. Table 3 presents difference between groups in terms of their attitude towards ICT.

Table No. 3: Multiple Comparison of Teacher Education Institution in Term of Attitude towards ICT

\begin{tabular}{|c|c|c|c|c|}
\hline (I) institution & (J) institution & $\begin{array}{l}\text { Mean } \\
\text { Difference (I- } \\
\text { J) }\end{array}$ & Std. Error & Sig. \\
\hline \multirow{2}{*}{$\begin{array}{l}\text { Elementary college of } \\
\text { Education Gilgit }\end{array}$} & College of Education Gilgit & 4.59 & 1.55 & 0.014 \\
\hline & Local Public University & $5.04^{*}$ & 1.38 & 0.002 \\
\hline \multirow[t]{2}{*}{ College of Education Gilgit } & $\begin{array}{l}\text { Elementary college of Education } \\
\text { Gilgit }\end{array}$ & $-4.59^{*}$ & 1.55 & 0.014 \\
\hline & Local Public Sector University & 0.44 & 1.79 & 0.970 \\
\hline \multirow[t]{2}{*}{ Local Public University } & $\begin{array}{l}\text { Elementary college of Education } \\
\text { Gilgit }\end{array}$ & $-5.04^{*}$ & 1.38 & 0.002 \\
\hline & College of Education Gilgit & -0.44 & 1.79 & 0.970 \\
\hline
\end{tabular}

Analysis shows a significant difference on attitude towards ICT between Elementary College of Education with other two teacher education institutions. The mean difference between Elementary College of Education and College of Education is $(\mathrm{M}=4.59, p=0.014)$. It indicates that there is a significant difference in attitude towards ICT of Elementary College of Education and the College of Education. Similarly, the mean difference between Elementary College of Education and the Local Public University is $(\mathrm{M}=5.05, p=0.002)$ showing a significant difference on attitude towards ICT between Elementary college of Education and the Local Public Sector University. However, the mean difference between College of Education and the Local Public Sector University is $(\mathrm{M}=0.44, p=$ 0.970). Since greater value of p i,e. 0.05 indicates no any significant difference in terms of participants attitude towards ICT between College of Education and the Local Public Sector University.

\section{Research Question Two}

How do attitude towards ICT and use of ICT for educational purposes varied among prospective teachers enrolled in different teacher education institutions?

In order to find out whether the prospective teachers' attitude towards ICT differed in accordance with the teacher education institutions, we compared the mean and standard deviation value. Table 4 presents the means and standard deviations for prospective teachers enrolled in three colleges of education with Attitude towards ICT.

Table No. 4 Descriptive Statistics Comparing Prospective Teachers' Attitude towards ICT Enrolled in Different Teacher Education Institutions

\begin{tabular}{lllll}
\hline Variable & Institutions & $\boldsymbol{M}$ & $\boldsymbol{S D}$ & $\boldsymbol{N}$ \\
\hline Attitude towards & Elementary college of Education & 103.40 & 8.72 & 139 \\
ICT & College of Education & 98.80 & 9.14 & 41 \\
& Local Public Sector University & 98.35 & 8.53 & 56 \\
\cline { 2 - 5 }
\end{tabular}

The mean value $(\mathrm{M}=103.4 ; \mathrm{SD}=8.72)$ of Elementary College of Education $(\mathrm{ECoE})$ is highest among all groups, which mean that the ECoE prospective teachers show high positive attitude towards ICT than the other two teacher education institutions. However, College of Education $(\mathrm{M}=98.80 ; \mathrm{SD}=9.14)$ and the Local Public Sector University $(\mathrm{M}=98.35 ; \mathrm{SD}=8.35)$ showed almost similar mean values with a small variations in standard deviations. In general, it can be concluded there is slight variation in perspective teachers' attitude towards ICT in different teacher education institutions. 
Moreover, A one-way analysis of variance (ANOVA) was used to assess the significance of the difference between attitude towards ICT vary among prospective teachers enrolled in different teacher education institutions in Gilgit. Table 5 presents variances in attitude towards ICT with Teacher Education Institutions.

Table No. 5 Attitude towards ICT with Teacher Education Institutions

\begin{tabular}{llllllll}
\hline Variable & $\begin{array}{l}\text { Teacher Education } \\
\text { institutions }\end{array}$ & $\boldsymbol{S S}$ & $\boldsymbol{D} \boldsymbol{f}$ & $\boldsymbol{M S}$ & $\boldsymbol{F}$ & $\boldsymbol{P}$ & $\boldsymbol{\eta}^{\mathbf{2}}$ \\
\hline Attitude & Between Groups & 1352.21 & 2 & 676.10 & 8.82 & 0.000 & 0.07 \\
towards ICT & Within Groups & 17858.73 & 233 & 76.64 & & &
\end{tabular}

A one-way ANOVA analysis showed a statistically significant difference between groups as $\left(F(2,233)=76.64, p<0.000\right.$. The effect size value (eta square $\left.=\eta^{2}=0.07\right)$ indicate a medium effect size of $7 \%$. The significant value confirms a significant difference in prospective teachers' attitude towards ICT among three teacher education institutions.

In order to assess the use of ICT for educational purposes mean values and standard deviations were calculated. Table 6 presents the means and standard deviations for use of ICT for educational purposes with teacher education institutions.

Table No. 6 Use of ICT among Teacher Education Institution

\begin{tabular}{llccc}
\hline Variable & Institutions & M & SD & N \\
\hline Use of ICT & Elementary college of Education & 55.97 & 11.42 & 139 \\
& College of Education & 58.46 & 9.62 & 41 \\
& Local Public Sector University & 58.50 & 9.51 & 56 \\
\hline
\end{tabular}

Mean values of Elementary College of Education $(\mathrm{M}=55.97$; $\mathrm{SD}=11.42)$, College of Education $(M=58.46 ; \mathrm{SD}=9.62)$ and Public Sector University $(\mathrm{M}=58.50 ; \mathrm{SD}=9.51)$ reveal no significant difference in use of ICT. Although there is not a big difference in terms of use of ICT among teacher education institutions. However, analysis reveals that the mean value of Elementary College of Education is slightly less than other two teacher education institutions. It means ECoE has slightly less use of ICT for educational purposes than other two teacher education institutions.

A one-way ANOVA was also conducted to assess whether use of ICT for educational purposes varied among teacher education institutions. Results are shown in Table 7.

Table No. 7 Use of ICT with Teacher Education Institutions

\begin{tabular}{lllllllc}
\hline Variables & & SS & Df & MS & F & P & $\boldsymbol{\eta}^{2}$ \\
\hline Attitude towards & Between Groups & 360.92 & 2 & 180.46 & \multirow{2}{*}{1.57} & 0.21 & 0.01 \\
ICT & $\begin{array}{l}26704 . \\
08\end{array}$ & 233 & 114.61 & & & \\
& Within Groups & & & & \\
\hline
\end{tabular}

Results indicate no significant difference among teacher education institutions use of ICT as indicated by one way ANOVA $(F(2,233)=1.57, p>0.000)$. Since, the value of $p$ is greater than 0.05 , therefore there cannot be statistical difference in use of ICT in teacher education institutions. The effect size value (eta square $=\eta^{2}=0.01$ ) indicated that there was a small effect size of $1 \%$. Research Question Three

What relationships exist among prospective teachers attitude towards ICT, use of ICT, gender, type of institution and program of studies?

Pearson Product Moment correlation was used to determine the direction and strength of relationship between the above-mentioned variables. Table 8 indicated the results of the correlation analysis for attitude towards ICT, use of ICT, gender, type of institution, and program of studies.

Table No. 8: Correlation Matrix indicating relationship between attitude towards ICT and other variables

\begin{tabular}{|c|c|c|c|c|c|}
\hline Variables & & Use Of ICT & Gender & Institution & Program of \\
\hline & $\mathrm{R}$ & $0.289^{* * *}$ & -0.033 & $-0.251^{* *}$ & $0.189^{* *}$ \\
\hline Attitude towards ICT & $\mathrm{P}$ & 0.000 & 0.613 & 0.000 & 0.004 \\
\hline & $\mathrm{N}$ & 236 & 236 & 236 & 236 \\
\hline
\end{tabular}




\begin{tabular}{cllll}
\hline \multirow{3}{*}{ Use Of ICT } & $\mathrm{R}$ & -0.056 & 0.107 & -0.078 \\
& $\mathrm{P}$ & 0.389 & 0.100 & 0.233 \\
& $\mathrm{~N}$ & 236 & 236 & 236 \\
\hline \multirow{3}{*}{ Gender } & $\mathrm{R}$ & & 0.072 & 0.020 \\
& $\mathrm{P}$ & 0.271 & 0.760 \\
& $\mathrm{~N}$ & 236 & 236 \\
\hline \multirow{3}{*}{ Institution } & $\mathrm{R}$ & & $-0.899^{* *}$ \\
& $\mathrm{P}$ & & 0.000 \\
& $\mathrm{~N}$ & & 236 \\
\hline
\end{tabular}

Analysis reveals weak positive correlations between ICT use and attitude towards ICT $(\mathrm{r}=$ $0.289, p=0.000)$, program of studies and attitude towards ICT $(r=0.189, p<0.004)$, gender and program of studies $(\mathrm{r}=0.020, \mathrm{p}=0.760)$, with shared variances of 8.3 percent; 3.5 percent; 0.04 percent respectively.

In addition, analysis showed a weak inverse correlations between gender and attitude towards ICT $(r=-0.033, p=0.613)$ gender and use of ICT $(r=-0.056, p=0.389)$, and type of institution and attitude towards ICT $(\mathrm{r}=-0.251, \mathrm{p}=0.000)$ with shared variances of 1 percent, 3 percent and 6.3 percent respectively. Moreover, a weak inverse correlations was also found between program of studies and use of ICT $(r=-0.078, p=0.233)$. The highest inverse correlation was found between program of studies and type of institution $(\mathrm{r}=-0.899, \mathrm{p}=0.000)$ with shared variances of 0.6 percent and 80.8 percent respectively.

On the basis of above results, it can be assumed that teachers attitude towards ICT has a positive relationship with use of ICT and program of studies. However, attitude towards ICT was found to have inverse correlation with gender and type of institution. Similarly, inverse correlation was observed between use of ICT and gender and use of ICT and program of studies.

\section{DISCUSSION}

The review of literature revealed that numerous research studies had been conducted on prospective teachers' attitude towards ICT and its use for educational purposes across the world (Ahmed \& Kazmi, 2020; Alzaidiyeen, Leong, \& Fook, 2010; Kaur, 2011; Mostert \& Quinn, 2009; Murray, Nuttall, \& Mitchell, 2008; Olakulehin, 2007; Oliver, 2002; Ozdamli, Hursen, \& Ozcinar, 2009; Qudais, AlAdhaile,h \& Al-Omari, 2010; Rana, 2016; Watson, 2005; Yuen \& Wong, 2003). Even though these studies provided valuable information, however, the findings were not generalizable to the teacher education institutions of Gilgit-Baltistan Pakistan due to contextual differences. Based on analysis and reviewed literature the study infers following main points:

Firstly, perspective teachers in general were found to have high attitude towards ICT. It was found that they enjoy using ICT because it makes their work interesting and improves the quality of their work. It seems that, ICT not only helps them to make their work better and interesting, but it makes their work enjoyable by utilizing it for recreational purposes such as using computer games. Similar findings are revealed by other research studies such as, Garland and Noyes (2004) conducted a research study on prospective teachers' attitude towards ICT and their findings revealed that prospective teachers enjoy ICT based learning. Similarly, a research study in Nottingham Trend University by Sam, Othman and Nordin (2005) revealed that prospective teachers enjoy delivering their lectures on multimedia and prefer to do tasks and assignments in laptops.

Secondly, teachers enrolled in different teacher education institution are found to have a slight difference in their attitude towards ICT. However, findings further indicated no significant difference in use of ICT among prospective teachers enrolled in different teacher education institution. A number of research studies supported these findings. For instance, researchers like (Imtiaz \& Maarop, 2014; Kaur, 2011; Mostert \& Quinn, 2009; Teo \& Schaik, 2012) found a significance difference among teacher education institutions in term of attitude towards ICT. However, few research studies (Bullock, 2004; Lim, 2007; Tezci, 2009; Yalın, Karadeniz, \& Şashin, 2007) contradict and they found no any significant variation in attitude towards ICT among teacher education institutions. Derscheid (2003) revealed that prospective teachers enrolled in different programs of different teacher education institution have no significant difference in their attitude regarding using ICT. However, research studies (Lepipnik \& Samec, 2012; Leaser, 2010; Mostert \& Quinn, 2009; Prestridge, 2012) indicate 


\section{Relationship between Prospective Teachers' Attitude Towards Information and Communication Technology}

no any significant difference among teachers in terms of use of ICT. Olakulehin, (2007) conducted his study in Nigeria and the findings revealed that prospective teachers enrolled in different teacher education institution have no any significant difference in using ICT for educational purposes. Hassan and Sajid (2012) indicates that all teacher education institutions offers same tasks and assignments and prospective teachers have to do it. Nevertheless, more access to ICT, better awareness about the use of ICT, organizational support and skills in use of ICT may be some of the factors that motivate teachers to use ICT. However, future researchers can explore the reasons behind differences in attitude towards ICT among these institutions.

Findings further indicated weak positive correlations between use of ICT and attitude towards ICT. These findings are in contradiction with many previous findings regarding correlation between use of ICT and students attitude towards ICT. For instance, a European Commission (2001) report asserts that students' having more expertise in computers have more positive attitudes towards ICT as compare to those who interact less with computers. Similarly, Rhema, \& Miliszewska (2014) and Jan (2018) reveal that access to technology correlates positively with the level of technology use. This finding conveys that teacher are aware of the utility and benefits of ICT, hence they use ICT in to making teaching and learning more beneficial.

Moreover, findings indicated weak positive correlations between program of studies and attitude towards ICT. Findings suggest that prospective teachers studying in different programs tend to have more positive attitude towards ICT. These findings may be due to the ICT courses offered as important subjects in all types of programs in elementary colleges and universities in Pakistan. Hence, students in such programs perceive technology as an important subject and understand its importance in practical life. Muslim (2010) indicated no significant difference between Art and Science students' attitude towards ICT.

Finally, positive correlation is also found between gender and program of studies. Number of previous research studies such as (Ertmer, Addison, Lane, Ross, \& Woods, 1999; Islahi \& Nasrin, 2019; Kubiatko, 2010; Wong \& Hanafi, 2007) indicated that male teachers own more positive attitude towards ICT as compare to female counterparts. It can be assumed that male are more inclined towards ICT and hence more inclined towards programs that offer ICT. Findings of this study propose that female students need to develop interest and positive attitude towards ICT to be part of programs that have ICT component in them.

\section{CONCLUSION}

From our research we may conclude that more than $90 \%$ prospective teachers show high positive attitude towards ICT and its use in education. The study proved that teachers in general have positive attitudes toward the use of technology. However, use of ICT in education should not be presumed as using it as a tool to transfer instructional material rather it should be used to facilitate learning processes. Use of ICT as a tool can be less effective in terms of enhancing students understanding of content and skills. Students and teachers need to learn with technology instead of learning from technology. In order to implement ICT with its full essence, teachers should be supported with appropriate facilities, training, support and resources. For the reason that, availability and accessibility of ICT resources and professional development opportunities for teachers may have additional benefits to students and teachers in terms of having positive attitudes towards ICT and the use of ICT in their learning regardless of the type and location of institute.

\section{Recommendations}

On the basis of above findings this study makes following recommendations:

1. For this research study, researcher has selected only final year prospective teachers in Gilgit as sample for data collection, because they have been taught two subjects regarding ICT in their course work and has more experience with ICT usage. Therefore, future research studies can be conducted on prospective teachers' attitude towards ICT in teacher education institutions across Gilgit and Baltistan.

2. It is highly recommended that researcher should look into the qualitative aspect of this research study. Qualitative research will help to deepen our understanding of unique characteristics that leads relationship between attitude towards ICT and its use for educational purposes. 
3. Successful integration and use of ICT in teaching and learning may depend strongly on the institution's support. Therefore, it is recommended that policy-makers should focus on improving institutional support towards use of ICT by updating institutions and providing them required technological resources and training.

\section{REFERENCES}

Abu Qudais, M., Al-Adhaileh, M., \& Al-Omari, A. (2010) 'Senior Faculty Members' Attitudes in Jordanian Universities towards Using Information and Communication Technology. International Arab Journal of eTechnology, 1, (4), 135-141.

Ahmed,S., \& Kazmi, H. H. (2020). Teacher Educators' Attitude towards the Pedagogical use of ICTs: A Study from Karachi. Pakistan. Journal of Education and Educational Development, 7(2), 369-386. http://dx.doi.org/10.22555/joeed.v7i2.67.

Ajzen, I., \& Fishbein, M. (2005). The Influence of Attitudes on Behavior. In D. Albarracín, B. T. Johnson, \& M. P. Zanna (Eds.), The handbook of attitudes (pp. 173-221). Lawrence Erlbaum Associates Publishers.

Al-Shboul, M. (2013). The Level of E-Learning Integration at the University of Jordan: Challenges and Opportunities. International Education Studies, 6, 93-113.

Alzaidiyeen, N., \& Leong, F. (2010). Teachers' Attitudes and Levels of Technology Use in Classrooms: The Case of Jordan Schools. International Education Studies, 3,(2),11-21.

Bhoomireddy, N., \& Bhatia, K. K. (2004). Fundamentals of Educational Technology. New-Delhi, Kalyani Publishers.

Bullock, D. (2004). Moving from theory to practice: An examination of the factors that preservice teachers encounter as the attempt to gain experience teaching with technology during field placement experiences. Journal of Technology and Teacher Education, 12(2), 211-237.

Derscheid, C. L. (2003). Early Childhood Educator's Attitudes Toward and Knowledge About Computers in the Classroom. Unpublished Doctoral Thesis, Dekalb: Northern Illinois University.

Dibattista, D., Mitterer, J. O., \& Gosse, L. (2004). Acceptance by undergraduates of the immediate feedback assessment technique for multiple-choice testing. Teaching in higher Education, 9 (1), 17-28.

Ertmer, P. A. (2005). Teacher pedagogical beliefs: The final frontier in our quest for technology integration?. Educational technology research and development, 53(4), 25-39.

Ertmer, P.A., Addison, Lane, P. S., Ross, M., \& Woods, D. (1999). Examining Teachers' Beliefs About the Role of Technology in the Elementary Classroom. Journal of research on computing in education, 32, 54-72.

Eurydice. (2011). Key data on learning and innovation through ICT at school in Europe. Brussels, Belgium.

Fraillon, J., Ainley, J., Schulz, W., Friedman, T., \& Gebhardt, E. (2014). Preparing for life in a digital age. The Iea International Computer and Information Literacy Study International Report. Amsterdam; IEA.

Friedman, T. (2005). The World Is Flat: A Brief History of the Twenty-First Century. New York: Farrar, Straus, and Giroux.

Garland, K. J., \& Noyes, J. M. (2004). Computer experience: a poor predictor of computer attitudes. Computers in Human Behavior, 20(6), 823-840.

Government of Pakistan (2009). National Professional Standards for Teachers in Pakistan, Policy and Planning Wing, Ministry of Education, Government of Pakistan, Islamabad Pakistan.

Gulbahar, Y. (2008). ICT usage in higher education: A case study on preservice teachers and instructors. Turkish Online Journal of Educational Technology, 7(1),32-37.

Hafifah, G. N. (2020). Teachers' Perspectives of ICT Integration in English Language Teaching: A Review of Literature. J. Eng. Educ. Society, 5(1),9-15.

Hardman, J. (2019). Towards a pedagogical model of teaching with ICTs for mathematics attainment in primary school: A review of studies 2008-2018.

Harindranath G, Dyerson, R., \& Barnes D. (2008). ICT adoption and use in UK SMEs: A failure of initiatives? Electronic Journal Information Systems Evaluation, 11(2): 91-96. 
Hassan, T., \& Sajid, A. (2012). ICTs in Learning in Pakistan. International Journal of Evaluation and Research in Education (IJERE), 1(2),51-61.

Ihmeideh, F. M. (2009). Barriers to the use of technology in Jordanian pre- school settings. Technology, Pedagogy and Education, 18(3), 325-341.

Imtiaz, M., \& Maarop, N. (2014). A Review of Technology Acceptance Studies in the Field of Education. Jurnal Teknologi (Sciences and Engineering), 69, 27-32.

Ion, P., \& Andreea, Z. (2008). Use of ICT in SMES management within the sector of services. The Journal of the Faculty of Economics-Economic, University of Oradea, Faculty of Economics, 4(1), 481-487.

Islahi \& Nasrin. (2019). Exploring teacher attitude towards information technology with a gender perspective. Contemporary Educational Technology, 10(1), 37-54. https://doi.org/10.30935/cet.512527.

Isleem, M. I. (2003). Relationships of selected factors and the level of computer use for instructional purposes by technology education teachers in Ohio public schools: a statewide survey (Doctoral dissertation, The Ohio State University).

Jan, S. (2018). Investigating the relationship between students' digital literacy and their attitude towards using ICT. International Journal of Educational Technology, 5(2), 26-34.

Kaur, A. P. (2011). Pre-service Science Teachers Attitude towards the use of selected ICT tools in Teaching: An Exploratory Study. Advancing Education Journal, Retrieved September, 4, 2021. From http:// www.naace.co.uk/1718.

Kalyanpur, M. \& Kirmani, M. H. (2005). Diversity and Technology: Classroom Implications of the Digital Divide. Journal of Special Education Technology, 20(4), 9-18.

Khan, M. S., Hasan, M., \& Clement, C. K. (2012). Barriers to the introduction of ICT into education in developing countries: The example of Bangladesh. International Journal of Instruction, 5(2), 61-80.

Khine, H., Dorfman, D. H., \& Avner, J. R. (2001). Applicability of Ottawa knee rule for knee injury in children. Pediatric emergency care, 17(6), 401-404.

Khokhar, A., \& Javaid, S. (2016). Students and Teachers Perceptions of ICT Use in Classroom: Pakistani Classrooms. The Asian Conference on Technology in the Classroom 2016 Official Conference Proceedings.

Kubiatko, M. (2010). Czech University Students' attitudes towards ICT used in science education. Journal of Technology and Information Education, 2, 20-25.

Kumar, S. A., Lo, P. H., \& Chen, S. M. (2008). Electrochemical selective determination of ascorbic acid at redox active polymer modified electrode derived from direct blue 71 . Biosensors and Bioelectronics, 24(4), 518-523.

Lepip nik-V, J., \& Samec, P. (2012). Advantages and disadvantages of information- communication technology usage or four year-old children, and the consequences of its usage for the children's' development. International Journal of Humanities and Social Science, 3(2), 54-58.

Lim, C.P. (2007). Effective integration of ICT in Singapore schools: Pedagogical and policy implications. Educational Technology Research and Development, 55(1), 83-116.

Ministry of Education (2009). National Professional Standard for Initial Preparation of Teachers in Pakistan. http://www.unesco.org.pk/education/documents/step/National\%20Professional\%20Standards $\% 20$ fo \%20Teachers\%20in\%20Pakistan.pdf

Morris, L., Xu, H., \& Finnegan, C. (2005). Roles of faculty in teaching asynchronous undergraduate courses. Journal of Asynchronous Learning Networks. 9, 65-82.

Mostert, M., \& Quinn, L. (2009).Using ICTs in teaching and learning: Reflections on professional development of academic staff. International Journal of Education and Development using Information and Communication Technology (IJEDICT), 5(5), 72-84.

Murray, S., Nuttall, J., \& Mitchell, J. (2008). Research into initial teacher education in Australia: A survey of the literature 1995-2004. Teaching And Teacher Education - Teach Teach Educ. 24. 225-239.

Muslim, I. M. (2010). The influence of CALL on students attitudes toward comprehension. College Of Education For Women, 21(3), 743-749. 
Olakulehin, F.K. (2007). Information and communication technologies in teacher training and professional development in Nigeria. The Turkish Online Journal of Distance Education, 8, 133-142.

Oliver, R. (2002). The role of ICT in higher education for the 21st century: ICT as a change agent for education.

Ongori, H., \& Migiro, S. O. (2010) 'Information and communication technologies adoption in SMEs: literature review'. Journal of Chinese Entrepreneurship, 2(1), 93-104.

Ozdamli, F., Hursen, C., \& Ozcinar (2009). Teacher candidates' attitudes towards the instructional technologies. Procedia Social and Behavioral Sciences, 1, 455-463.

Prestridge, S. (2012) The beliefs behind the teacher that influences their ICT practices. Computers \& Education, 58(1), 449-458.

Rana, N. (2016). A study to assess teacher educators' attitudes towards technology integration in classrooms. MIER Journal of Educational Studies, Trends and Practices, 2(2), 190-205.

Rhema, A \& Miliszewska, I. (2014). Analysis of Student Attitudes towards E-learning: The Case of Engineering Students in Libya. Issues in Informing Science and Information Technology, 11, 169-190.

Roussos, P. 2007. The Greek computer attitudes scale: Construction and assessment of psychometric properties. Computers in Human Behavior, 23(1),578-90

Sam, H. K., Othman, A. E. A., \& Nordin, Z. S. (2005). Computer self-efficacy, computer anxiety, and attitudes toward the Internet: A study among undergraduates in Unimas. Journal of Educational Technology \& Society, 8(4), 205-219.

Smith, B., Caputi, P., \& Rawstorne, P. (2000). Differentiating computer experience and attitudes toward computers: An empirical investigation. Computers in Human Behavior - Comput Hum Behav, 16, 59-81.

Straub, E. (2009). Understanding Technology Adoption: Theory and Future Directions for Informal Learning. Review of Educational Research - REV EDUC RES. 79, 625-649.

Teo, T., Luan, W.S., \& Sing, C. C. (2008). A cross-cultural examination of the intention to use technology between Singaporean and Malaysian pre-service teachers : An application of the Technology Acceptance Model (TAM). Educational Technology \& Society, 11 (4), 265-280.

Teo, T., \& Schaik, P. (2009), Understanding technology acceptance in pre-service teachers: A structuralequation modelling approach. The Asia-Pacific education researcher, 18(1), 47-66.

Tezci, E. (2011). Factors that influence preservice teachers' ICT usage in education. European Journal of Teacher Education, 34, 483-499.

Torkzadeh, G., J.C.J. Chang, and D. Demirhan. (2006). A contingency model of computer and Internet self-efficacy. Information \& Management, 43(4),541-50.

Watson, D. (2006). Understanding the relationship between ICT and education means exploring innovation and change. Education and Information Technologies, 11(3), 199-216.

Wong, S., \& Hanafi, A. (2007). Gender Differences in Attitudes towards Information Technology among Malaysian Student Teachers: A Case Study at Universiti Putra Malaysia. Educational Technology \& Society, 10, 158-169.

Yalin, H., Karadeniz, O. \& Oahin, S. (2007). Barriers to Information and Communication Technologies Integration into Elementary Schools in Turkey. Journal of Applied Sciences, 7(24),4036-4039.

Yekini,N. (2014). Information Communication Technology (ICT) [Concepts and Application]. 10.13140/RG.2.1.1802.7289.

Yuen, H. K., \& Wong. (2001). Teachers' computer attitudes: Factors influencing the instructional use of computers. In Proceedings of the International Conference on Computers in Education 2001, Novemeber 2001, Korea. Incheon National University of Education..

Zhao, Y., Tan, H. S. \& Mishra, P., (2001). Teaching and learning: Whose computer is it? Journal of Adolescent \& Adult Literacy, 68 (2). 46-52. 